\title{
The Role of Pandji Masjarakat During the Guided Democracy Period
}

\author{
Teguh Prasetyo \\ Literature Department, Faculty of Humanities, \\ Universitas Indonesia, Depok, Indonesia \\ Syarif Hidayatullah State Islamic University Jakarta, Indonesia \\ teguh.prasetyo.uiegmail.com
}

\author{
M. Yoesoef \\ Literature Department, Faculty of Humanities \\ Universitas Indonesia, Depok, Indonesia \\ Syarif Hidayatullah State Islamic University Jakarta, Indonesia \\ yoesoev@yahoo. com
}

\begin{abstract}
During the times of Guided Democracy, absolute power over the whole nation was held by Soekarno's hand. Consequently, Soekarno had total control of various government regulations, ncluding the ones pertaining to politics and culture. This provoked responses from different groups, organizations, and political parties. Particularly, these responses came in forms of affirmation, attempts of coalition, and criticisms. It was not uncommon then for the media to accommodate a certain group's diverse voices and responses towards the Guided Democracy. One of these media was Pandji Masjarakat magazine. Affiliating to Muhammadiyah movement, the magazine had a close relation to MASJUMI. It was within this context that Pandji Masjarakat published many writings responding to socio-political conditions, and such trait was also available in its published literary works. Using sociological criticism, this paper examines Pandji Masjarakat's 1959-1960 publications of literary works (poems and short stories) which contain voices responding to the Guided Democracy's socio-political conditions. The result of the research reveals that Pandji Masjarakat voiced out both criticisms and affirmations towards Soekarno's leadership during the Guided Democracy period. Furthermore, these criticisms and affirmations were determined by the magazine's interest and organizational affiliations.
\end{abstract}

Keywords-Guided Democracy; Muhammadiyah; Pandji Masjarakat; Soekarno; Sociological Criticism

\section{INTRODUCTION}

The dawn of Guided Democracy was the beginning for an era of Soekarno-centric power. Power was subsequently dominated by Soekarno's personality, ideas, and jargons [1], [2]. According to Ricklefs (1995), this Soekarno-centric form of power mimics pre-colonial Javanese concepts of power, but imbued with Soekarno's utopistic ideas and empty promises.

Such Soekarno-centric power brought numerous impacts on the country's various dimensions, ranging from politics to culture. Jones [2] proclaims that as the center of power at the time, President Soekarno was the sole agent of fundamental decision-making. The President also declared "ManipolUSDEK" (the 1945 constitution, Indonesian Socialism, Guided Democracy, Guided Economy, and National Identity) as a pillar and reference of many regulations. In fact, every regulation on culture must be based on the principle, taking cultural regulations to the realm of national identity [2].

The formation of government which centered on Soekarno triggered responses from different groups and political parties. Those who agreed with Soekarno's ideas showed their support and made a coalition. However, others who disagreed voiced out their challenges and criticisms. Nevertheless, these challenges, resistance, and criticisms reached a dead end [1].

Responses to the government and the existing sociopolitical conditions during the Guided Democracy period was frequently written in various media as at the time, there were affiliations between the existing media and certain groups, organizations, or political parties. One of the media which spoke and responded to the existing socio-political condition was Pandji Masjarakat magazine. Aligning itself with Muhammadiyah, some suspected that the magazine was also tied to MASJUMI as Pandji Masjarakat's editors and key figures were either merely close to or even former supporters of MASJUMI. Articles and columns published in the magazine also frequently displayed congruency with Muhammadiyah and even MASJUMI's worldview.

Pandji Masjarakat gave its voices not only through its articles, but also through its publications of literary works. This is an intriguing aspect as according to Puar [3], Islamic themes were ubiquitous in these writings. Focusing on this aspect, this research attempts to examine socio-political voices conveyed by Pandji Masyarakat's publications of literary works during the Guided Democracy period, which occurred between 1959 and 1960. In addition, this paper attempts to interpret these voices through their relation to the magazine's ideology and its surrounding socio-political contexts.

In 1959-1960, Pandji Masjarakat published 86 poems, 9 short stories, and 1 play script. However, this paper will focus on several selected works which are considered to represent the era's socio-political opinions.

Pandji Masjarakat has been formerly investigated by Pratiwi Setiawati [4] in her writing Pandji Masjarakat 19661974: Upaya Memperjuangkan Idealisme Islam. Nonetheless, the research merely gives a descriptive examination on Pandji Masyarakat's historical and ideological development from the first time it was established to 1974. Moreover, the writing focused its data in articles published from 1966 to 1974, leaving a niche for a more comprehensive research on 19591960 publications. With this research gap, this paper expects to describe the role and voices of Pandji Masjarakat during the Guided Democracy period through arguments voiced out within the magazine's literary works.

\section{METHOD}

In investigating the corpus, this paper uses the approach of sociological criticism through close reading technique. The 
approach is based on a perspective that every literary work cannot be dismounted from its contexts of creation and publication. Tanaka [5] argues that there is no text which "falls from the sky". Social, political, economic, and cultural issues are always present in a text's background, paving the way of a text's birth and publication. In addition, Swingewood [6] also asserts that a literary writing is a mirror for a social condition. Swingewood's term "mirror" does not refer to a social context's mere reflection. It also refers to the depiction of a society, which has formerly gone through a writer's formulations based on his or her experiences and interaction with the society. In other words, a literary writing's depiction of society is often embedded with distractions from the writer's or the publisher's ideological perspectives. This results in a condition in which literary writings can be a tool for an ideology's proliferation [7].

\section{RESULT AND DISCUSSION}

Pandji Masjarakat was published for the first time on June 15, 1959. Publishing biweekly, there were 10,000 copies sold in its first month of publication. The magazine then increased its production to 15,000 copies before finally distributing 21,000 copies in its first year [8].

Known as Pandjimas, this magazine proclaimed to have no orientation to any groups or political parties. Nevertheless, the magazine was believed by many to have a connection with Masjumi and Muhammadiyah. In particular, some of the editors, namely M. Yunan Nasution and M. Faqih Usman, had been formerly active members of the Masyumi party and Muhammadiyah organization [4]. Nonetheless, according to Surjomihardjo (1980), Pandji Masjarakat's orientation to Muhammadiyah sources from its two predecessory roots, Pandji Islam and Pedoman Masjarakat, which were magazines with Muhammadiyah tones. Subsequently, Pandji Masjarakat carried a perspective similar to Muhammadiyah's, which is Islamic Modernism. In this context, Islamic Modernism brings forward the development ethics or tajdid (renewal, reformation, and purification). On top of that, Islamic modernism constantly defended Islamic movements, founding its gist on Amar Ma'ruf Nahi Munkar, a phrase from the Al-quran and Sunnah (Baraas, et. al, 2000).

In articles written by Usman (1959), modernism also refers to enlightenment to both conservatives and "Westworshippers" alike. Enlightening the conservative can be interpreted as leading them away from rigid traditionalistic paradigms, while enlightenment to the "West-worshippers" may cover ideas of anti-colonialism, anti-imperialism, and even anti-communism. In addition, Usman [9] argues that the magazine's model of modernism refers to guarding one self from the dangers of materialism and atheism.

Islamic Modernism ideologies made Pandji Masjarakat to frequently discuss the Guided Democracy's social and political conditions, and these discussions often come in forms of criticisms to Soekarno-centric model of power written in the magazine's published articles. Starting from articles discussing the Democratic League (which opposed the Guided Democracy), the resistance reached its peak in the publication of “Our Democracy” (Demokrasi Kita) written by Moh. Hatta himself [10]. Interestingly, this article led to both proliferation and stagnation of the magazine's number of sold copies. Soon after "Our Democracy" was published, many readers asked for more copies. However, on the other hand, as Moh. Hatta's writing harshly criticized Soekarno's leadership, labelling him "a dictator" and declaring a crisis in Soekarno's governance, the article also put Pandji Masjarakat's existence in jeopardy.

It is important to note that "Our Democracy" was merely an apex of the accumulation of criticisms delivered by former articles, which had similarly criticized the Guided Democracy while simultaneously showing signs of supports to the Democratic League, a forum in which MASJUMI was recorded to be one of its members. All these critiques resulted in government's ban of Pandji Masjarakat as it was considered contradictory to the government of Guided Democracy's regulation. The ban was announced through the government's 19 Articles regarding newspaper.

Aside from its articles, Pandji Masjarakat's publication of literary works also delivered contesting voices against the Guided Democracy's socio-political conditions. As previously mentioned, there were myriads of literary publications by Pandji Masjarakat between 1959-1960, and reviewing each would be impossible. This subchapter then aims to review several poems and short stories as samples of work which opposed the Guided Democracy.

One of the works which clearly voiced out its criticism towards the socio-political conditions of the Guided Democracy is the poem Di Atas Pusara by Ndang Adi Nusantara [11]. Written in a form of ballad, the poem depicted a person on a pilgrimage to a war hero's tombstone. The pilgrim made a monologue on several issues, including liberty and government.

\section{III}

Liberty that once was be the ground where stood the shackled

Liberty that is now is in jail, in shackles

-How plenty the oddity that men do in its name!

Justice that once was be the hopes and dreams of the convicted

Justice that is now is by the discourteous court convicted

--How plenty the partisans that are dragged to trial!

Truth that suffers is about to be defeated

Truth that stays strong will never be defeated

--How plenty its seekers that are put to gallows!

[11, p. 21]

It is clear that the quotation marked the poet's attempt to compare between the past and "now" (his contemporary) in depicting his condition. There is a sense of regret for the existing condition as if the fallen heroes' struggles became vain. "Liberty" has been shackled, "Justice" has been convicted by the court, and "the truth" is about to be defeated. These metaphors seem to describe a circumstance which corners the poet, signaling that the condition where the poem 
was written was full of injustice. The pilgrim shows that there are parties who discourteously manipulate freedom, especially one that is according to the character's sense.

Putting the surrounding context of the poem into consideration, this poem could be interpreted as a criticism towards the authoritarian dictatorship of the Guided Democracy. The tone resembles articles published by Pandji Masjarakat, particularly "Our Democracy". In addition, the narration formed by the poem seems to depict MASJUMI's struggle. According to Ricklefs [1], this struggle in resisting against the Guided Democracy was done hand-in-hand with PSI and several other minor parties which at the time opposed Soekarno's leadership, but the struggle was constantly neutralized. Such can be interpreted from the phrase "how plenty the partisans that are dragged to trial". The word "partisan" may refer to political parties and some of their members who, in this context, are considered in line with the character (the pilgrim). On the other hand, "put to gallows" seemingly gives hints at party members who were trialed and eliminated.

Another work which depicted the socio-political context of the Guided Democracy was the poem Dialah Wujud dan Abadi by El Jatim DA [12]. The poem itself mainly consists of a theme of gratefulness to God, but it also contains rhetorics which corner those who do not believe in a god.

$\cdots$

Once Lenin and you deny the supernatural

Kufur your embodiment will become

And true purity will drive his lifeless body to regret

My thoughts are supernaturality in the realm of science

But none of this the deaf may hear

For blind the atheists' spiritual eyes be

$[12$, p. 22]

The quotation shows that there was a narration which positioned Leninists and similar groups as "faithless", "deaf", "atheists", and "spiritually blind". These words are certainly loaded with negative connotations. These linguistic features are apparently a part of an attempt to construct a discourse justifying those who have religions, other-ing Leninists and similar groups.

Relating the literary work to the context of the magazine's ideology, the poem has transformed into a medium which Damono [7] calls as "the tool of ideological proliferation". The magazine's version of modern ideology denied communism, and such denial was portrayed through a poem's rhetorics, creating a narration that it is impossible Leninists and Communists to obtain God's blessings. Politically, the narration served as a signifier of oppositional stance towards communism, which was a party which was considered close to Soekarno.

Aside from poems, there were several several stories which joined the rally of criticizing their current sociopolitical conditions. For instance, a short story by Djamil Suherman, Turunnja sebuah Ilham [13]. Although it mainly tells the story of a writer's difficult life at the time, there are also instances of criticisms to the government.

He knows that Hafidah, his wife, is in her late pregnancy. And he knows that the baby will be born just before Eid al-Fitr. This means that he will become a father of four children. Certainly, the arrival of this God's servant will require more money to call a paranormal and buy jamu, besides (ah, this will be another burden to bear) Lebaran. Like it or not, as a rural person he needs to act accordingly [13, p. 31].

The quotation displays how the writer faced his difficult life, particularly in dealing with the issue of poverty. In particular, the character's financial problem faces the challenge of his own necessities, which kept on coming. Furthermore, his writings were not published, and he did not get any money. Nonetheless, the story resolved in religious symbolisms of adzan and a mosque tower, symbolizing religiosity and religious practices.

Similarly, the narration of poverty also ocurred in $\mathrm{M}$. Rasjid Nur's short story, titled Dia dan Kemauannja. The work tells a story of a medicine seller who had a family conflict as he decided to sell medicinal goods outside of the town. His decision of leaving the town was entailed by many misfortunes. His ill child finally died, and, being out of town, the medicine seller could not even see the child for one last time.

Even so, he fails to triumph over the bitter life which conceals him over and over. Nor can he stand against the storm of poverty that chokes him day by day.

The money that comes from his relentless shouts sometimes barely covers his travel expense [14].

The excerpt narrates the character's difficulty in facing his poor life. There is a narration in which the medicine seller had to leave his own child in order to sell medicine due to difficult financial situation at the time.

Both of these short stories brought forward the issues of poverty and financial difficulties, and these can be seen as another criticism to Soekarno's Guided Economy. During the time, Indonesia's economic condition was going through terrible (hyper)inflation, causing a downfall in the country's overall financial condition [1]. Additionally, Vikers [15] also reveals that from late 1950 s to early 1960 s, prices of goods soared, and bad weather contributed to the country's feeble economic condition. Besides this, religious symbols were also used to reinforce people and give people hope to live a better life. This use of religious symbols seemed to show a rhetorics declaring that religiosity is the best way out of all the troubles.

The four works mentioned above have a common similarity in criticizing the Guided Democracy. Nevertheless, there were also voices which showed affirmation to the government. These voices were also accomodated by Pandji Masjarakat, and this is evident in a poem titled Bandung, 
written by Mohammad Mahmoud Ridwan [16], the poem resembles an Ode, containing compliments and even worships to Indonesia and Bandung. Several metaphorical and lyrical expressions became words which personified the writer's amazement to Indonesia. However, these admirations seem to be conveyed solely because of ideas of liberty, antiimperialism, and friendship between Asian and African countries.

\author{
Shelter for wanderers from faraway be \\ In the beloved Gedong Merdeka (building of liberty) \\ Fate of the future will be decided \\ There the voice of peace enroots \\ The swordsman hacks, the swordsman slashes \\ And so to each other two continents embrace, Asia- \\ Africa \\ Unlocked the shackles be, now souls rejoice in \\ liberty \\ Winds of hope waft and clamor \\ Nehru, Soekarno, and Nasser [16]!
}

Taken from the last stanza, the quotation describes both Bandung and the idea of liberty. As Indonesia was depicted as a place where liberty was formulated and a location where Asia and Africa greeted together in a warm embrace, this shows the author's glorification of Indonesia in his poem. In other words, there is a narration which romanticizes the Asian-African conference, which was the extension of Soekarno's ideas and leadership. In addition, the poem mentions great hope on Nehru, Soekarno, and Nasser. This solidifies the idea that Soekarno, along with his ideas and leadership, was a noble figure to whom nations and the human race looked up to.

If one considers the context, the spirit of anti-imperialism was in line with modern ideologies brought forward by Pandji Masjarakat and its affiliates. It is also important to note that Hamka, an important religious figure who was a key editor of the magazine, played an important role in maintaining good relations with Egypt, another third-world country which resonated the spirit of anti-colonialism and anti-imperialism [17]. In brief, the publication of Bandung and its affirmative narration to Soekarno's leadership was strongly related to the magazine's ideological congruency, interest, and affiliations.

During the Guided Democracy era, Pandji Masjarakat's voices and roles in conveying its aspiration through different works, especially literature, can further be interpreted as a form of political action in supporting organization to which it affiliated, which were Muhammadiyah and MASJUMI. In this case, Pandji Masjarakat appeared to represent Muhammadiyah's Islamic aspirations, particularly in either criticisms or supports to the existing government. Voices which were conveyed in forms of scientific, cultural, and literary articles became something which was rather positive. If one examines the development of Islamic media in the Reformation Era, especially in 2017, Pandji Masjarakat could be a good reflection in proclaiming Islamic ideologies and political voices. The form of scientific and literary articles of Pandji Masjarakat's 1959-1960's publications could be an exemplary method which actors of Islamic thoughts and political voices can look up to.

\section{CONCLUSION}

This paper's analysis leads to a conclusion of two aspects. First, Pandji Masjarakat was an Islamic magazine which affiliated itself with Muhammadiyah and was close to MASJUMI. This affiliation proves ideological congruency, particularly in Islamic Modernism. On top of that, the articles of the magazine represented both Muhammadiyah and MASJUMI's voices in criticizing the Guided Democracy's government. Second, the literary works of Pandji Masjarakat also played a part in voicing out attitudes towards sociopolitical conditions of the Guided Democracy. Depending on the magazine's ideology, interest, and affiliation, some opinions voiced out criticisms while others displayed tones of affirmation. The criticisms sourced from the magazine's modern ideology, which was in line with Muhammadiyah and MASJUMI's narration of opposing the Guided Democracy's nuances of Marxism and Communism. On the other hand, affirmative voices focused on Soekarno's ideas of anticolonialism and anti-imperialism, which, in this part, supported the magazine and its affiliate's ideology. Aspirations and political voices embedded in scientific and literary articles in Pandji Masjarakat's 1959-1960's publications can be a sufficiently positive and significant model for the development of Islamic thoughts and politics.

\section{REFERENCES}

[1] M.C. Ricklefs, Sejarah Indonesia Modern. Yogyakarta: Gajah Mada University Press, 2007.

[2] Tod Jones, Kebudayaan dan Kekuasaan di Indonesia: Kebijakan Budaya selama Abad ke-20 hingga Era Reformasi. Jakarta: Pustaka Obor, 2015.

[3] J. A. Puar, "Posisi Sastera nan Bernafaskan Ketuhanan: Persadjakan Islam dalam menghadapi Individualisme, Naturalisma, dan Realisme Proletar," Pandji Masjarakat, vol. 15, pp. 12-14, 1960.

[4] P. Setiawati, "Pandji Masjarakat 1966-1974: Upaya Memperjuangkan Idealisme Islam," Undergraduate thesis, Universitas Indonesia, Indonesia, 2006.

[5] R. Tanaka, System Models for Literary Macro-theory. Lisse: Peter de Rider Press, 1976.

[6] A. Swingewood and Dian T. Laurenson, Sociology of Literature. New York: Shocken Books, 1972.

[7] S. D. Damono, Sosiologi Sastra: Pengantar Ringkas. Ciputat: Editum, 2010.

[8] M. J. Ahmad, "Setahun Pandjimas," Pandji Masjarakat, vol. 25, p. 5, 1960 .

[9] M. F. Usman, "Sebab Pandji Masjarakat Diterbitkan," Pandji Masjarakat, vol. 1, p. 2, 1959.

[10] M. Hatta, "Demokrasi Kita," Pandji Masjarakat, vol. 22, pp. 3-8, 1960.

[11] N. A. Nusantara, "Di Atas Pusara," Pandji Masjarakat's, vol. 11, 15Nov-1959.

[12] E. J. D. A., "Dialah Wujud dan Abadi," Pandji Masjarakat, vol. 8, 01Oct-1959.

[13] D. Suherman, “Turunnja sebuah Ilham," Pandji Masjarakat, vol. 20, 28-Mar-1960.

[14] M. Rasjid Nur, "Dia dan Kemauannja," Pandji Masjarakat, vol. 23, pp. 25-26, Mei-1960.

[15] A. Vickers, A History of Modern Indonesia. UK: Cambridge University Press, 2005.

[16] M.M. Ridwan, "Bandung," Pandji Masjarakat, vol. 6, p. 23, Sep-1959. 
[17] H. Salim, "Muslim Indonesia dan Jaringan Kebudayaan," in Jennifer Lindsay dan Maya H. T. Liem. (ed.) (2011). Ahli Waris Budaya Dunia: Menjadi Indonesia 1950-1965, Jakarta: KITLV Jakarta, 2011. 